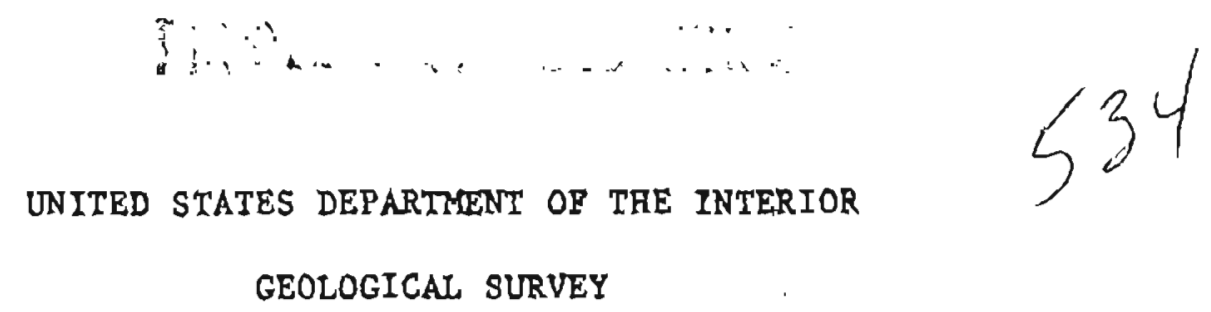

\title{
METAL PROVINCES OF AIASKA
}

By

\begin{abstract}
Allen L. Clark, Henry C. Berg, Edward H. Cobb, G. Donald Eberlein, Edward M. Mackevett, Jr., and Thomas P. M1ller
\end{abstract}

Open-f1le report

1972

This report is preliminary and has not been edited or reviewed for conformity with Geological Survey standards 
METAL PROVINCES OF ALASKA

By

Allen L. Clark, Henry C. Berg, Edward H. Cobb, G. Donald Eber1ein, Edward M. Mackevett, Jr., and Thomas P. Miller

Demands for information pertalning to the geology and resource potential of Alaska have been steadiby Increasing, but although the known mineral occurrences and deposits have been discussed in many publicationg and summarized in compliations (Berg and Cobb, 1967; Cobb, 1972), there has not yet been an analysis of the reglonal distribution of minerals throughout the state. To fill this need, maps were prepared that show major and minor mineral deposits and generallzed geology, and that tentatively outline major metal provinces. Such information will be useful in formulating decisions on land-use and will provide a basic Eramework for metal-exploration programs.

The development of a metal province map requires a great deal of subjective reasoning. The accompanying maps are only a first attempt and will no doubt be modyfied and superseded as additional data become available and present data are refined.

\section{Bastc assumptions}

Without detailed information concerning the age, controls, and genesis of most mineral deposits in Aleska, nelther a metallogenic provInce map not a metallogenic epoch map can be prepared. However, it is possible to map the distribution of kindred or diagnostic metals in large regions of Alaska. The present map was therefore prepared within 
the framework of the following deflnition: "A metal province is any area, ranglng in size from an entire reglon to a single mining district, which Is characterized by a distinct association and(or) anomelous concentration of a metal or metals."

Using this definttion, large areas of Alaska were Identified as metal provinces on the basls of known lode and placer depostts, geochemlcal sampling, extrapolation of known geologic environments, and the subjective evaluation of geologists who are experts on the various regions of Alaska.

In developing the map it was necessary to conslder the following factors:

1. In most parts of the State Ifttle fnformation is avallable. However, in some areas which have been studied extensively, such as the Seward Peninsula, the information level is relatively high. Therefore, in most areas it was necessary to extrapolate metal province boundaries through areas of $11 t$ te-known geology and locally whthout known deposits on the assumption that the geology was comparable to betcer-known metalliferous areas. In general, euch extrapolations were "stralght-IIne." As more data become avallable, the boundaries of the provinces may change considerably or the province may be found to be as continuous or extensive as postulated. In the better studled areas, the boundarieg of the provInces are expected to change very little and only as a result of reflnement of known geologic parameterg.

2. Mineral development in Alaska is in an early stage, resulfing primarily from remoteness and the high cost of exploration, extraction, 
and marketing of metals. Consequently, minlng ventures have concentrated on commodities of high unit values, such as gold, sllver, platinum, mercury, and high-grade massive copper depostes. Thts has infected a strong blas in the definttion of the major metal provinces of Alaska. To lessen this bias, particular attention was given to the knowo but less well-developed deposits of each area in determining how to categortze a given metal province. No provinces were deflaed solely on the basts of placer occurrences as placer deposits are considered to represent a residual concentration of metale govemed by speciflc gravity, solubility, and graln size, wh1ch might or might not represent the true metal "slgnature" of an area. Placer deposit districts are shown by Cobb (1972) fox all of Alaska.

$$
\text { References cited }
$$

Berg, H. C., and Cobb, E. H., 1967, Metalliferous lode deposits of Alaska: U.S. Geol. Survey BuI1. 1246, 254 p.

Cobb, E. H., 1972, Placer deposlts of Alaska: U.S. Geol. Survey open-f1le report. 